\title{
The Materiality of the New Family House in Hungary: Postsocialist Fad or Middle-class Ideal?
}

\author{
KRISZTINA FEHÉRVÁRY \\ University of Michigan, Ann Arbor
}

\section{Abstract}

In the social and economic upheaval during the first decade after the fall of state socialism in Hungary, the emergence of new neighborhoods of detached family houses outside of a former "socialist city" provoked ambivalent reactions. Were these homes the natural housing form for an emerging middle class in newly independent, freemarket Hungary, or a passing fad led by the nouveaux riches? This article argues that that the eventual triumph of this suburban housing form had little to do with an inevitable trajectory of capitalism modeled on that of the West. Instead, it was a unique material and aesthetic form that, in the Hungarian context, was aligned with the values of its rural precedents while at the same time distinguished from them as "middle class." The materiality of the new family house has not only redefined the conditions for belonging to the ranks of a new middle class, but has been instrumental in constituting and legitimating this emerging class. [suburbanization, housing, middle class, state-socialism, postsocialism, Hungary]

$\bigcirc$ f the many transformations to the Hungarian landscape after the fall of state socialism, one of the most striking was the emergence of small "suburbanized" neighborhoods of detached family houses. These areas were situated on the outskirts of towns or at the edges of existing villages, carved out of agricultural land. Distinctive architectural styles set these houses apart from pre-socialist peasant houses as well as the more modern houses built during the decades of state socialism ( I 948-1989). Instead of productive gardens and areas for livestock, these new houses flaunted elements of leisure and decorative display: gazebos, lawns, flowerbeds and fountains, birdbaths and fishponds. A plethora of stylized media images of the single family house with a red-tiled roof accompanied the emergence of these new houses. Referred to by Hungarians as the "family house with garden" (kertes családi ház), the image was used in advertisements for everything from building materials and home insurance to the grand prize in productrelated raffles.

This architectural development was particularly noticeable in Dunaújváros, the socialist "new town" where I carried out my anthro-

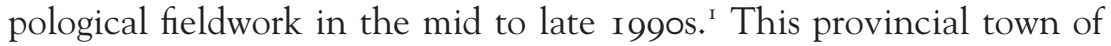
under 60,000 people had been built in the early i950s on agricultural fields on a plateau above the Danube River as a model, planned town adjacent to a new steel factory. It had borne the name Sztálinváros or 


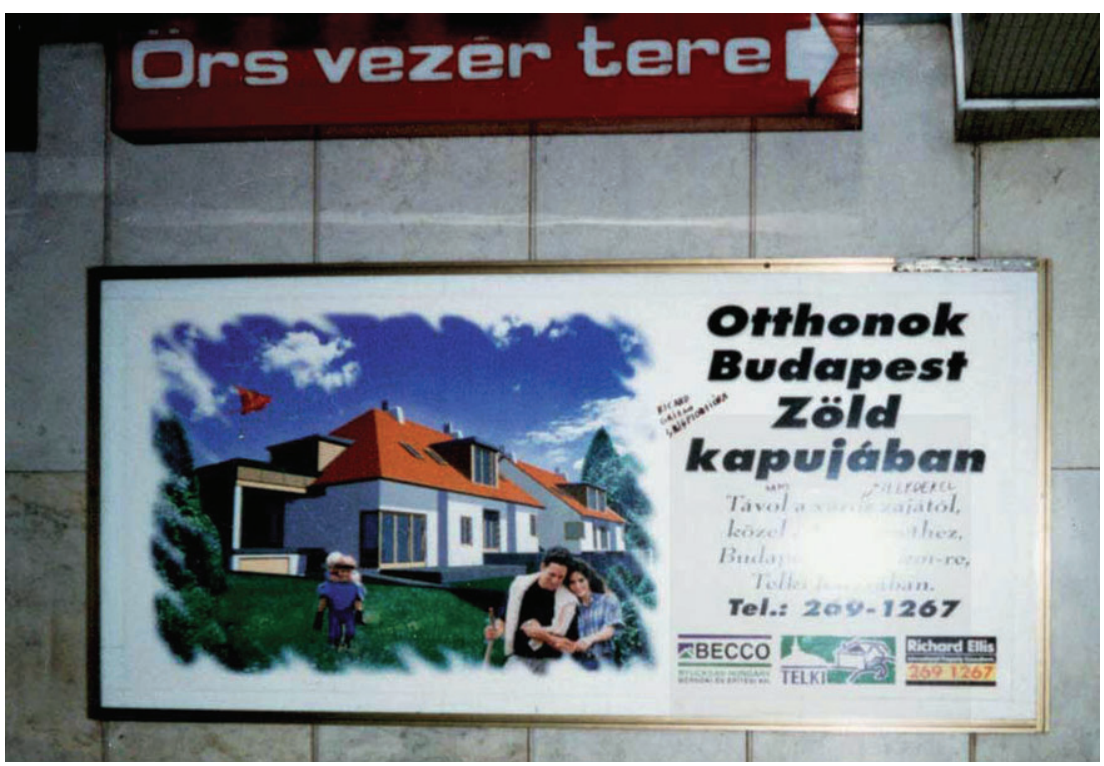

Figure I. Advertisement in the Budapest subway for housing development outside of the capital city, reading: "Homes in Budapest's Green Gate," and displaying an iconic image of the family house with red-tiled roof and loving family. Photo by author.

"City of Stalin" until I96I, when it was renamed Dunaújváros or "New City on the Danube." After the collapse of state-socialism, 85 percent of the town's population continued to live in the multi-story concrete blocks of apartments which comprised most of the city. Nonetheless, in an interview the city planner stated matter-of-factly: "Everyone who can is moving out to a family house." Like many Hungarians (as well as many western observers), she considered the family house phenomenon to be a natural response to the new economic and political reforms of bourgeois capitalism, a continuation of long term Hungarian practices and values, and a sign that Hungary belonged in Europe. ${ }^{2}$ Even to observers more critical than the city planner, the houses seemed to fit a familiar story of suburbanization. The overpowering image of oppressive urban public housing being replaced by private, detached homes reinforced conventional understandings of a transition from state socialism to market capitalism, whereby socialist welfare and the collective values it stood for are replaced by neoliberal regimes that seek to produce self-governing, autonomous subjects.

And yet, such surface similarities are misleading. Socialist Hungary was unusual in leaving most homes in private ownership after I948, and much of the apartment block housing constructed by the socialist state after the I96os was owner-occupied from the start; what remained of state-owned housing was quickly privatized in I99I-92. While Hungarians were well-aware of suburban middle-class culture elsewhere, such a housing form and the conditions for its existence (infrastructure, private cars, and the notion of a commuting middle class) still had to be constructed for most of Hungary. ${ }^{3}$ Construction of these new houses was neither facilitated by the economic policies of the new state, nor were they embraced by the socialist-era professional, managerial and 


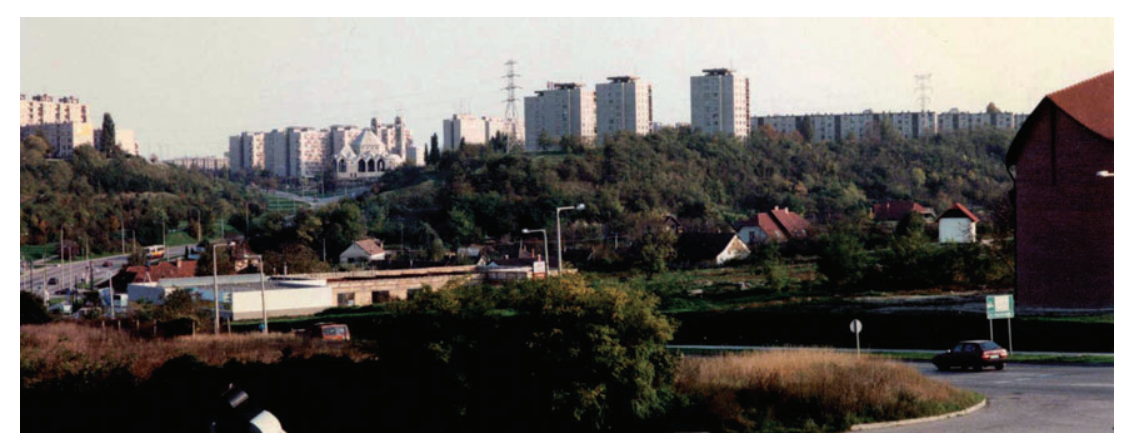

Figure 2. Dunaújváros in 1997. Panel construction apartment buildings on the plateau behind old and new family housing in the village below. Photo by author.

white-collar classes living in the new town-many of whom regarded them with a mixture of skepticism and distaste. In order to become accepted and valorized as an appropriate dwelling form for a modern and respectable middle class, the "family house" had to overcome lingering associations with rural backwardness and worker-peasant lifestyles. It also had to deflect associations with the elaborate villas of corrupt socialist-era political elites and the new villas of an equally corrupt postsocialist economic elite (Czegledy i998). To add to these obstacles, economic conditions for building were worse than they had been for years. Nonetheless, by the end of the I99os, the aspiring middle classes in Dunaújváros had either embraced or capitulated to the notion that such a house was a defining element of middle-class respectability.

The widespread acceptance of the new family house with garden was accomplished, I will argue in this article, through its material and aesthetic forms. These forms appropriated and transformed the existing values they indexed and the kind of lifestyles they appeared to make possible. The new suburban house legitimated its presence on the landscape (and that of its inhabitants) through a symbolic opposition to the apartment blocks of state socialism. These houses also distinguished themselves from their rural neighbors through a distinctive aesthetic drawing on new materials, technologies and building methods. Yet house builders and their advocates were nonetheless able to align this new house form with values as they had become materialized in their rural precedents: the houses built during the socialist ig6os to I980s, as well as the weekend or summer cottages of a socialist middle stratum. New houses that were of markedly postsocialist construction and style also provided the space for realizing norms and ideals for respectable, middle-class life. The costs of participation in this new house form excluded a large number of people who had considered themselves to be members of a respectable, socialist middle stratum, but they also offered others, once excluded from such a stratum, the possibility of admittance to an emerging middle class (cf. Freeman 2007). The new suburban house was thus a material form around and through which an otherwise diverse population began to coalesce and differentiate itself.
The Materiality of

the New Family

House in Hungary

by the end of the

I990s, the

aspiring middle

classes had either

embraced or

capitulated to the

notion that a

house was a

defining element of

middle-class

respectability. 
Others have addressed similar processes of social differentiation and conflict through housing in the ongoing development of suburbs and in the rise of a commercial real estate sector in the United States and elsewhere, such as in China (Zhang 2008). In these cases, the design and construction of new dwellings is done primarily by commercial developers with varying degrees of involvement by the state-which might provide the necessary infrastructure or guarantee financing. In Hungary, by contrast, little new housing outside of the metropolitan capital of Budapest has been built by such schemes since 1990. Just as during the socialist period, most new family houses continue to be designed and constructed piecemeal, each one the private project of an individual or family in a process called "self build" or "autoconstruction" (Holston I99I). The role of this house form in constituting a new middle class has been as much in the production process itself as in how it is consumed and appropriated. This process demands resources and labor, mobilizes contacts, draws upon and innovates architectural styles, and facilitates (or obstructs) bodily and social practices. ${ }^{4}$ It can thus provide us with a picture of the heterogeneous forces at play in producing a provincial middle class in Hungary, one smaller and differently constituted than the socialist middle stratum that preceded it.

Private home-ownership and social stratification through living space have long operated as markers of status, but they have also been a means through which middle-class culture is formed. In other words, beyond simply reflecting new social stratifications, we can see the new family house as constitutive of a new kind of middle class. In making this argument, I am building on the work of scholars who take the materiality of the built environment into consideration in their analysis of social and cultural processes, demonstrating how the material objects that people produce in turn serve to produce people; as Nancy Munn has shown, objects and subjects can be reciprocal agents of each other's value (Munn 1986). In Daniel Miller's work on modern mass production and consumption, social relations are produced by as much as reflected in the ways people select, exchange, and consume material goods (Miller 1987; 2005). In the case at hand, the emerging middle class is being produced by these new residential spaces, not only by how they are decorated and what they symbolize, but in how such material worlds provide new "affordances and constraints" (Tilley 2007:19) to socializing, to activities such as cooking, cleaning and gardening, to movement and other bodily experience, and to new possibilities for privacy. Thus we can see how the material properties of these houses vastly exceed their role in representation (Keane 2003, 2006). For example, our experience of a room is shaped in part by whether its walls can keep out the cold as well as the sounds of neighbors and the street. Finally, I have attempted to be attentive to what Bruno Latour has provocatively called the agency of things (Latour 2005), meaning that built environments must be seen as networks of human and non-human actors whose capacities are not wholly projections of human intention or the results of human action. 
n I994, Laura, the owner of a small English language school in Dunaújváros, embarked with her new husband upon building a large, detached "family house" on agricultural land in the outskirts of a nearby village. Like most city residents, Laura had lived all of her 35 years in small, urban apartments. Because her father was a doctor, her childhood home had been relatively spacious. It had an entry-way, a main room with a balcony, one bedroom, a kitchen large enough for a small table and chairs, and a bathroom and W.C. As was customary in "good families," the bedroom was the "child's domain" (gyerekbirodalom). Laura's parents slept on a pull-out couch in the multifunction living room, and every morning stowed the bedding in cabinets. When Laura married her first husband, she moved to a smaller two-room apartment, and when her daughter Virág was born, she was given the only bedroom. In contrast, the new house was set in a large, enclosed garden, and featured cathedral ceilings with an exposed second floor (with space for several additional rooms), three finished bedrooms, two-and-a-half baths, a kitchen open onto the living room, and a two-car garage. Laura was particularly thrilled about the separate laundry and sewing rooms.

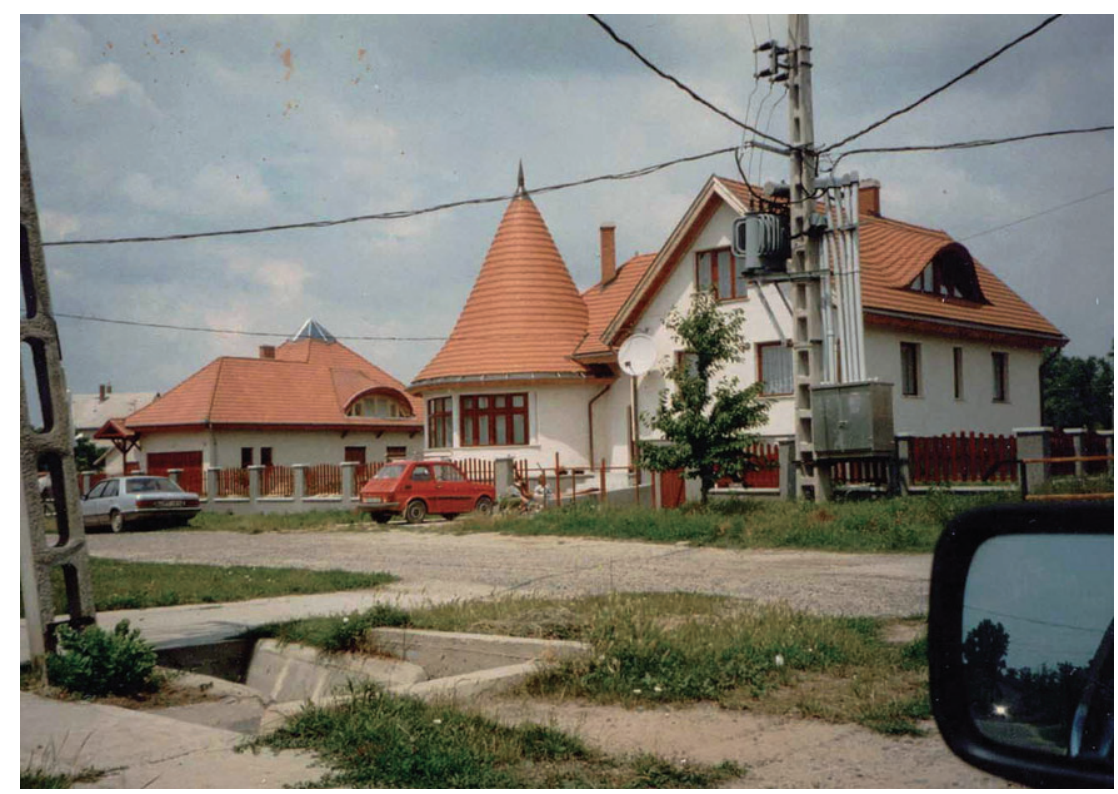

Figure 3. New middle class houses in a village I2 kms outside of Dunaújváros, featuring red tile roofs and rounded forms. 1997. Photo by author.

Laura's ambitions for her house were on the extravagant side for the time, placing her among the first to build this kind of new home on the edges of a village $15 \mathrm{~km}$ from the town. But her desire for a substantial transformation of her living environment was shared by increasing numbers of people. Some middle-aged professionals were considering a move to a family house, while others moved to better apartments within the city or embarked on transformations to their interior spaces. A few intrepid residents had managed to blast through poured concrete walls of 
apartments to create the coveted "American kitchen" (amerikai konyha) or kitchen open to the living area. Bathrooms were upgraded as space and ingenuity allowed, linoleum replaced with ceramic tile. Throughout the socialist-era buildings, old, uniform front doors, often made of PVC, were replaced with wood doors or personalized with a brass door knocker or name plate. These new construction and renovation projects, undertaken at a time of great economic uncertainty, were often achieved at an expense far beyond a family's means (Magyar Nemzet i 996/Io/I 5).

In the decade following the regime change, the transforming landscape was often narrated via a "discourse of the normal" which divided the material world between spaces and objects that conformed to Hungary's new geo-political status and thus assisted in its integration into a European order, and those that remained largely unchanged, part of a discredited socialist past (Fehérváry 2002). Within this context, Hungarians aspiring to or identifying with middle-class status faced an imperative to adopt material signs of postsocialist status and to normalize them in everyday life, aligning themselves symbolically and discursively with the postsocialist order (cf. Rausing I 998). As with emerging middleclasses in other peripheral nation-states, the material requirements for local middle-class belonging are often dictated by commodified images and consumer goods depicting middle-class respectability in a "first world" (Liechty 2003; Foster 2002; O'Dougherty 2002). Such materialities carry with them the promise of a set of benefits on a global scale: a full "humanity" conferred by coeval status with the West, moral legitimacy, respectability, local status, and a host of other, materially-enabled desires-many of them firmly grounded in a comfortable home.

In the former socialist new town of Dunaújváros, these distinctions were felt particularly acutely. Residents were well aware that in the rest of the country, this city was understood to be one of the "ugliest" in Hungary, an exemplar of Soviet city planning and modern architecture. Here, as elsewhere in the country, the transformation of the material environment according to post-socialist norms was central to the establishment of a collective and individual presence in a transformed present - even as they were alarming signs of the disruption of a familiar social order and moral code. The material forms of new houses are thus carefully evaluated to judge the moral legitimacy of those they shelter.

\section{From the middle stratum to a middle class:}

\section{Idealized social groups and their materialities}

$\square$

ungarian national politics after the fall of state socialism was dominated by a neoliberal ideology which greatly influenced the

direction of sweeping institutional reforms. As with new governments across the region, Hungarian politicians considered the reestablishment of private property central to the political legitimacy of the new order, a position that was also required by international actors such as the IMF and the World Bank as a condition for loans (Verdery 2003:3). 
Privatization of state-owned housing in particular was seen as "essential to ending the dependency of citizen on the state" (Ruble r995:29). In Hungary, the moral correctness of private property as an institution was at times equated with the restoration of the country as an independent, Christian nation-state - as in the following editorial on the front page of the Dunaújváros newspaper: "St. Stephen [Hungary's patron saint] made Christianity the law of the land, but also sanctified the law of property" (Dunaújvárosi Hírlap, 8/1996:I).

At the same time, the instability of financial institutions prevented the new regime from doing more than rapidly divesting itself of stateowned property, including the privatization of apartments in housing blocks. Politicians discussed the importance of establishing some kind of mortgage system, but until the 2000s, inflation and economic insecurities limited the scope of these plans, and with it, the development of a real estate sector. ${ }^{5}$ In metropolitan Budapest, private (often foreign) developers began to build multi-story "residential parks" as well as villa style and lower-rise developments (Bodnár and Molnár 2010), targeting a population of expatriates and a new crop of Hungarian entrepreneurs and professionals often working for foreign companies. But Dunaújváros and other small provincial towns were not an appealing prospect for real estate developers, particularly for the residential market. The primary form of new residential construction was therefore through the timehonored practice of families building houses for themselves, either through exchanges of collective labor or a newer system of piece-meal contracting.

Despite these limitations, an unopposed assumption in politics and the media was that Hungary's future as a democratic nation-state depended upon the emergence of a strong middle class based on private property. As Polish anthropologist Michal Buchowski has written, "the new middle class [in eastern Europe] is a concept influenced by teleological ideas of 'transformation,' and it plays an ideological role in the building of the new liberal political and ideological order" (2008:49). The size, character, and viability of this elusive middle class were bitterly contested. The term "middle class" (középosztály) was often used interchangeably with "middle stratum" (középréteg) or "bourgeois citizenry" (polgár), though the significance of these three terms differed. Use of "middle class" itself was a new thing. Talking openly about class made explicit the new legitimacy of economic inequalities in a market democracy, and some politicians talked of the resurrection of an historic bourgeoisie. But all grappled with how a large, socialist-era middle stratum was to fare within the new order.

The term "middle strata" had been coined by Hungarian sociologists in the r 960 s to describe the middle layers of socialist society as they were defined by position, income and modern consumer lifestyles - and to sidestep reference to traditional class hierarchies and inherited status. ${ }^{6}$ This broad, middle stratum was not an epiphenomenon of a socialist organization of production, but an explicit goal of the state's modernizing projects. Even in the Stalinist I950s, industrialization campaigns were
The Materiality of

the New Family

House in Hungary

In metropolitan

Budapest, private

developers began

to build

multi-story

"residential parks"

as well as villa

style and

lower-rise

developments 
paired with attempts to civilize "backward" populations into a modern, urban working class-in part through cultural programs (theater, classical music, literacy) but also through modern apartments, consumer goods, and new standards for hygiene. By the r96os, Communist-bloc states began to take seriously the need to improve standards of living, in part to ameliorate social unrest, but in part as an extension of the Cold War to the realm of consumer culture. In Hungary, the Kádár regime was unique in how far it was able to push market reforms within the framework of a planned economy. Material benefits for skilled-labor, management and white-collar workers, and the profits generated by second-economy activities, resulted in economic inequalities and the emergence of new systems of distinction (Róna-Tas I 997, S. Nagy I 987).

The socialist state's promotion of a modern, discerning consumerism and the cultivation of good taste contributed to the development of what Mark Liechty calls a normative, "middle-class culture," in which respectability is tied to the acquisition of modern consumer goods and living environments (Liechty 2003). Home décor magazines, women's journals, newspaper editorials and film clips admonished the growing population living in small apartments to replace traditional furniture with modern versions, even if they had to make it themselves. With an open floor plan, tastemakers opined, Socialist citizens could divide small spaces into areas accommodating the needs of diverse individuals - an entertainment center for the man of the house, the sewing table for the wife/ mother, and the all-important "children's corner" so that the child could develop a sense of having his or her own, inviolate domain for toys and study (Bánk i 967). At the same time, space for a designated bedroom and for a family dining area, even in the kitchen, was considered superfluous; multipurpose furniture such as the pull-out sofa resolved the problem of sleeping, and designs for already small kitchens were progressively reduced in size, eroding the institution of the large family meal.

By the I970s, the vast middle stratum had expectations for an urban apartment, with modern, labor-saving appliances and television; occasional cultural outings and vacations; and a weekend cottage in the countryside. The state-run media explicitly encouraged comparison of this lifestyle, presented as a benefit of living in a socialist state, with that of average citizens in the First World. And in fact, while their forms and timing differed, there were many parallels in the kinds of societal transformations taking place in the Euro-American west and in socialist Hungary, particularly the extension of middle class status to a far greater percentage of the population through modern housing and respectable consumption. While cookie-cutter suburban houses with lawns were a symbol of postwar prosperity for the U.S., even for the average worker (Jackson I987; May I988), in Hungary the ideal modern lifestyle consisted of the stimulation of the city in an urban apartment during the work week, balanced by a weekend relaxing in the quiet, fresh air of a rural cottage and garden. For example, the longtime director of the Dunaújváros steel mill, one of the most powerful men in Communist Hungary, lived in one of the few four-room apartments in the city and had 
a tidy weekend cottage on the banks of the Danube. This middle-stratum culture was discursively positioned between an uncouth proletariat, backward peasants and poor Roma (gypsies) on the one hand, and the remnants of an old-fashioned bourgeoisie or déclassé gentry on the other.

While in hindsight the I970s are remembered as a time of relative prosperity, the economic crises and market reforms of the I980s meant that many Hungarians were moon-lighting in second economy jobs just to maintain their standard of living. Thus, as the middle stratum increasingly defined their harried experience of modern, daily life as abnormal, they idealized the lifestyles they imagined their counterparts in western Europe and the United States enjoyed—somewhat ironically, given that neoliberal reforms were having similar effects on middle-class life there. The conditions for a "normal" life and personhood, including such transcendent values as family harmony and self-realization, were understood to reside in material worlds as they existed in "normal" parts of the world. With the end of state socialism and the obstacles it presented, members of socialist middle stratum fully expected to constitute the new Hungarian middle class, finally able to realize lifestyles commensurate to their professional positions. Instead, most found themselves struggling to "keep up" their social status in the face of economic and institutional upheaval (Berdahl 1999; Fehérváry 2002; Patico 2008).

References to a historic middle class, or bourgeois-citizenry (polgár), were openly used in politics only after I989-indeed, became the name of the dominant conservative, nationalist Party. ${ }^{7}$ The state-socialist regime had somewhat successfully disrupted the material basis for traditional class hierarchies, but had been less successful in discrediting them as cultural categories. The significance of the term polgár after socialism stemmed from how it had been developed as part of an oppositional discourse during the socialist era. An urban bourgeoisie had never been the symbolic embodiment of Hungarian national values and culture, as it had been associated with "foreign" elements in Budapest, primarily of German and Jewish origin engaged in capitalist enterprise in the late $19^{\text {th }}$ and early $20^{\text {th }}$ centuries. Instead, the site of an authentic Hungarian nation had in the past been on the land, associated with an autonomous peasantry and gentry values.

In the late I970s, a dissident intelligentsia revived and revalued this bourgeois category. Drawing in part on Habermas's Structural Transformation of the Public Sphere, translated into Hungarian in I97I, writers like György (George) Konrád ( 1984 ) proposed that a sphere of autonomy from the state-a kind of anti-political civil society-might be developed based on second economy activities. The domestic social relations and material trappings of this bourgeois private sphere were a fundamental part of its idealization. ${ }^{8}$ For many people, as cultural geographer Judit Bodnár notes, "the ideological attack on the bourgeoisie effectively made anything 'bourgeois' an element of a desirable past" (Bodnár 2007:I42). For some of the urban intelligentsia, the use of polgár referred to hopes for the revival of latent political and cultural dispositions as much as economic practices (Ferge 1997:19). For others, the notion of polgárosodás
The Materiality of the New Family House in Hungary

the economic crises and market reforms of the I 980 meant that many Hungarians were moon-lighting in second economy jobs just to maintain their standard of living 
(embourgeoisment) was more often used to mean transforming the mentalities of the entire population: eradicating mentalities of entitlement and dependence on the state, reforming slack work habits, and fostering risk-taking, entrepreneurial activities as well as civic responsibility (Szelényi i988).

The ascendance of this bourgeois category came with an open devaluation of socialist values and of the working class, a class increasingly associated with an unnatural form of government as well as with characteristics of dependency and lack of initiative. The socialist state participated in this shift in class values in the I980s, not only through economic reforms but by officially recognizing that a small-scale entrepreneurial stratum would "continue to contribute for some time to the life of socialist society." "The socialist state also threatened unemployment as a measure to "discipline" the working classes who were depicted in the official media as lazy and shiftless.

For many Hungarians, and particularly for an aspiring middle class in Dunaújváros, the celebration of a Hungarian bourgeoisie in the I99os implied the privileging of those who could claim some form of polgár ancestry, and thus the restoration of a form of social stratification that had been discredited for forty years. For the majority of the population who had no real claim to polgár status, as well as for many who did, contemporary models of middle-class life and ostensibly merit-based social structures to be found in western Europe or the United States were far more appealing. Moreover, once disparaged occupations like the manager and entrepreneur were rapidly shifting in value from ambiguous

Television shows, to heroic. As we will see below, the role of the mass media in constructing decorating

magazines and

pull-out sections in

Materializing a new middle class

newspapers

continuously

exposed the

population to new

W

hile there was little agreement as to what type of person was constituting a new Hungarian middle class in the I990s, images of the range of material trappings for this class were everywhere. Television shows, decorating magazines and pull-out sections in newspapers continuously exposed the population to new designs for housing, for interior decoration and renovation. Just as in the socialist period, people continued to be attentive to the material settings of foreign movies and television shows. These were understood to be the settings for average, middle-class families-not of course the decor of designs for Dallas, which many people thought was tacky-but that of movies like Steve Martin's Father of the Bride (Shyer I99I) where the family lives in housing, for

interior decoration an enormous house with an open kitchen and a living room decorated entirely in white. It was precisely the unmarked quality of these material worlds, incidental to the plot or story line that implied a taken-forand renovation granted, "normal" standard of living.

Images of such material worlds came as much from Hungarian sources as from imports. Television, print media and retail spaces continuously exposed the population to representations of "appropriate" 
material environments for self-respecting Hungarian citizens. Furniture store displays, interior decorating shops and Home Depot-style DIY stores did the same, reinforcing the notion that such upgrades to one's living space were necessary to mark one's place in the postsocialist order. Regularly featured was the classic interior of the historic, urban bourgeoisie or polgár, ensconced in spacious apartments filled with antique furnishings, alien origins conveniently forgotten. The setting equated with an urban professional class, surrounded by high-tech modern décor or variations of IKEA, was also ubiquitous and situated in either older buildings or socialist-era estates. The setting for an autonomous, entrepreneurial middle class, however, was invariably a detached family house with a roof of bright red tile.

\section{The trouble with the family house}

$\uparrow$ he ideological power of this new, suburban house form came as much from its symbolic opposition to the built environment of state socialism as from idealizations of western models. In the simple aesthetic code of the post-socialist era, the values state-socialist rhetoric had assigned to these two housing forms were inverted. Housing estates were being equated with the past, with discredited ideals of collectivism, and with a denigrated urban proletariat, while the detached family house was acquiring new value as materializing the autonomy, property rights, and prestige of a new, capitalist middle class. ${ }^{10}$

For Dunaújváros's former middle stratum of professionals, educators, civil servants and skilled workers, however, such ideological rhetoric did not align with their experience of single-family housing forms during the decades of state socialism. Housing forms had been heavily implicated in state-socialist ideology of egalitarianism, the development of a classless society, the eventual elimination of private property and full urbanization. Urban apartment buildings, whatever their exact design, had been assumed to be the appropriate housing form in all iconography of the socialist future. In contrast, the private family house had been politically condemned as a vestige of the past, conducive to private individualism whether in the backward peasant house or urban bourgeois villa. This political rhetoric was backed by policy, as state investment in infrastructure privileged the development of urban environments at the expense of the rural. At the same time, in order to ameliorate continuing housing shortages, the state not only permitted but planned for families to build their own housing outside of cities. As early as the I950s, the state made provisions for single-family houses built by their future occupants, even in the model socialist town of Dunaújváros (Pittaway 2000). When the Party revealed its controversial i 5-year housing plan of i 960, it projected that such self-built housing would account for a full 40 percent of the million units it claimed would be built over the period, the rest to be built by the state in the form of urban apartment buildings. ${ }^{\text {II }}$ By the I98os, self-built housing had surpassed state construction in both quantity and quality (Hegedüs r 992:224). 
And yet, the increasing prevalence of self-built, single-family houses did not make them a symbol of middle stratum respectability, particularly in regions like Dunaújváros where pre-socialist era bourgeois villas were few and the models for the self-built family house were the Kuria (or manorial estate) on the one hand and the houses of a diverse peasantry on the other. The preference for an apartment during socialism had more to do with the conditions for acquiring and living in one as compared to the conditions for building a house. Obtaining a state-owned apartment often involved a years-long wait, but once allocated it was a good deal: low rents, free maintenance, and the option to bequeath the rights to the apartment to one's offspring. In contrast, the "self-built" mode of house production was arduous and lengthy, lasting anywhere from two to ten years. The strain entailed risks to family relations and marriages. The challenges of obtaining materials was endless, while labor was extracted from extended family, friends and through a rural system of exchange for building houses called kaláka (Sik I988). The saying "to throw oneself into building" (Belevágni az építkezésbe) acknowledged the Herculean challenges of "doit-yourself" housing (Kenedi i98 I). Severe housing shortages meant that for many Hungarians, particularly of the working classes, self-build was the only route to acquiring their own homes. ${ }^{\mathrm{I} 2}$ The state encouraged such building through pronatalist policies, offering young couples building loans and outright grants for each child they promised to have, even as it did little to make the building itself any easier. Market reforms beginning in the late ig6os meant that many such self-built village houses became spaces for profitable second-economy endeavors, for raising livestock and growing produce (Róna-Tas I997).

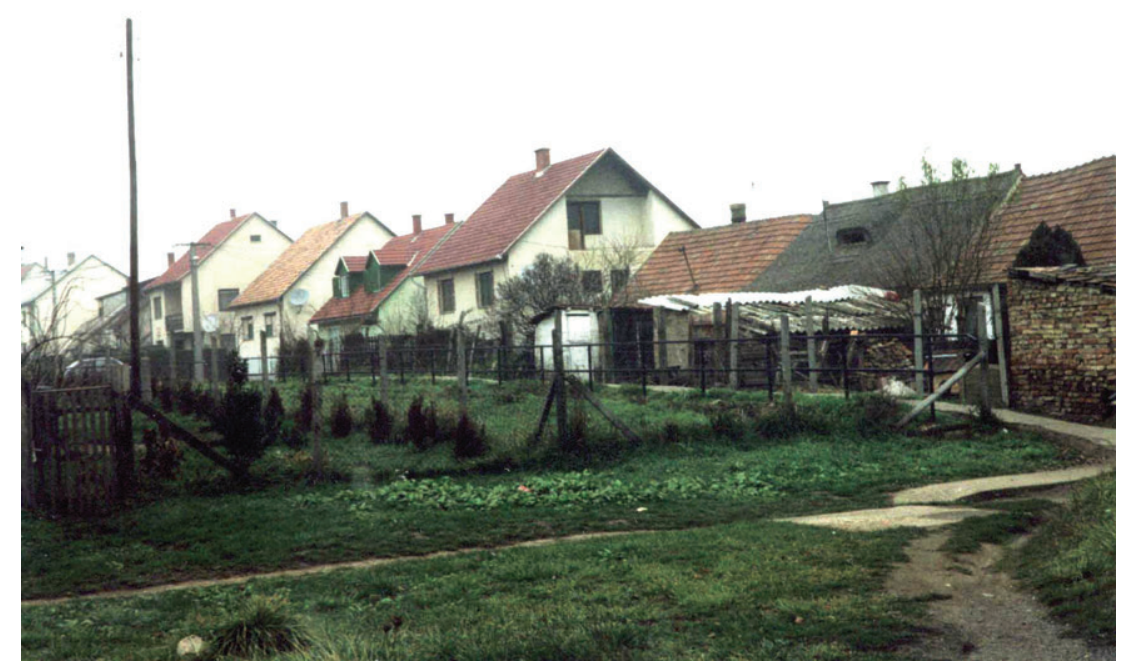

Figure 4. Self-built houses from the I980s on the left, alongside older peasant houses on the right, near to a suburbanizing area of a village $20 \mathrm{~km}$ from Dunaújváros. Photo by author.

In Dunaújváros, the socialist middle stratum never embraced the family house form, despite the centrally-located "garden city" neighborhood that had been set aside for such buildings (Miskolczi i980). The 

rural-entrepreneurs and worker-peasants, those who had the contacts and knowledge of village life to mobilize kaláka practices, and who did not shy away from the dirt and back-breaking labor involved. In contrast, centrally-located and state-owned apartments were among the most prestigious in the city, housing a greater number of professionals, many of whom had been lured to the provincial backwater of a town by the promise of an apartment. Even though most of these central apartments were built during the Stalinist period, they were of much higher quality than those built using panel concrete technology after I960-with parquet floors, higher ceilings and thicker walls. These apartments were also exceedingly difficult to acquire, particularly as the state gradually phased out construction of state-owned apartments in favor of cooperative-style buildings requiring a substantial down-payment.

Thus well into the postsocialist I990s, media representations of the new, red-roofed family house were set against a landscape where actual instantiations of such buildings were a novelty, a new residential housing form provoking both admiration and concern. Indeed, the response of many of this socialist middle stratum in Dunaújváros to the family house continued to be ambivalent, particularly among those 40 or older. In one case, a former Party official's daughter had built a spacious new loft apartment in the city, in the same building that her parents and grandmother had apartments, but had sold it to build a "family house with garden" in a nearby village. The Party official felt that her daughter had been taken in by "a passing fad" of the nouveau riches, echoing the condemnatory rhetoric of modernist architects in debates about housing in the rg6os and 7os (Major and Osskó I98I). In another case, a sociologist at the local Junior College insisted that her colleague, who had just built herself a family house, was what she called, rather disparagingly: "the property-owning type ... someone who lives to work on her house and garden." The sociologist, for her part, claimed to prefer living in her urban apartment during the week, and doing a little gardening in the fresh air of her cottage garden on the weekends. For her, urban life was equated with a desirable and morally-imbued sociality. As she put it: "I like social life, to visit friends for a quick coffee, or to pop downstairs to go shopping. I would feel isolated in a family house."

Such resistance to the family house was most often expressed by people who adhered to an older way of life gradually being challenged by the emergence of new alternatives. Claims to respectability based on profession or education, for example, might not be honored in a new socio-economic order. Indeed, for a significant proportion of Dunaújváros's former middle stratum, a family house of any kind was simply out of reach. With the exception of new family grants, the government had frozen support for new house building. During the I 990 , bank loans were difficult to obtain, even at the interest rate of 28-32 percent, and a mortgage system had not yet been developed. Inflation meant the price of building materials was skyrocketing. Moreover, the new family house forms that were set off from the family houses of

For a significant

proportion of

Dunaújváros's

former middle

stratum, a family

house of any kind

was simply out of

reach 
socialist peasant-entrepreneurs by scale and design also involved a new mode of production. ${ }^{\mathrm{I}}$

Changes in modes of production served to widen the perceived gulf that was growing between house builders still building using forms of kaláka, and those using newer, contract services-differences that were materialized in the resulting structures. Kaláka was on the decline as stonemasons, electricians and plumbers were able to command high prices on an open market, and new time constraints meant that neighbors and friends were no longer as able or willing to lend their services. It was being replaced by a newer type of building called öneró (selfpowered), which relied on the labor of immediate family, some hiredhands (often illegal immigrant Romanian-Hungarian laborers), and professionals where needed. This building mode, which used more skilled labor, was able to take advantage of new building materials and technologies to produce the prototypical family house of the new middle class. At the same time, it was in turn distinguished from housing that was entirely contracted to professionals. Political cartoons often revealed the disconnect between older forms of self-build and newer, contract

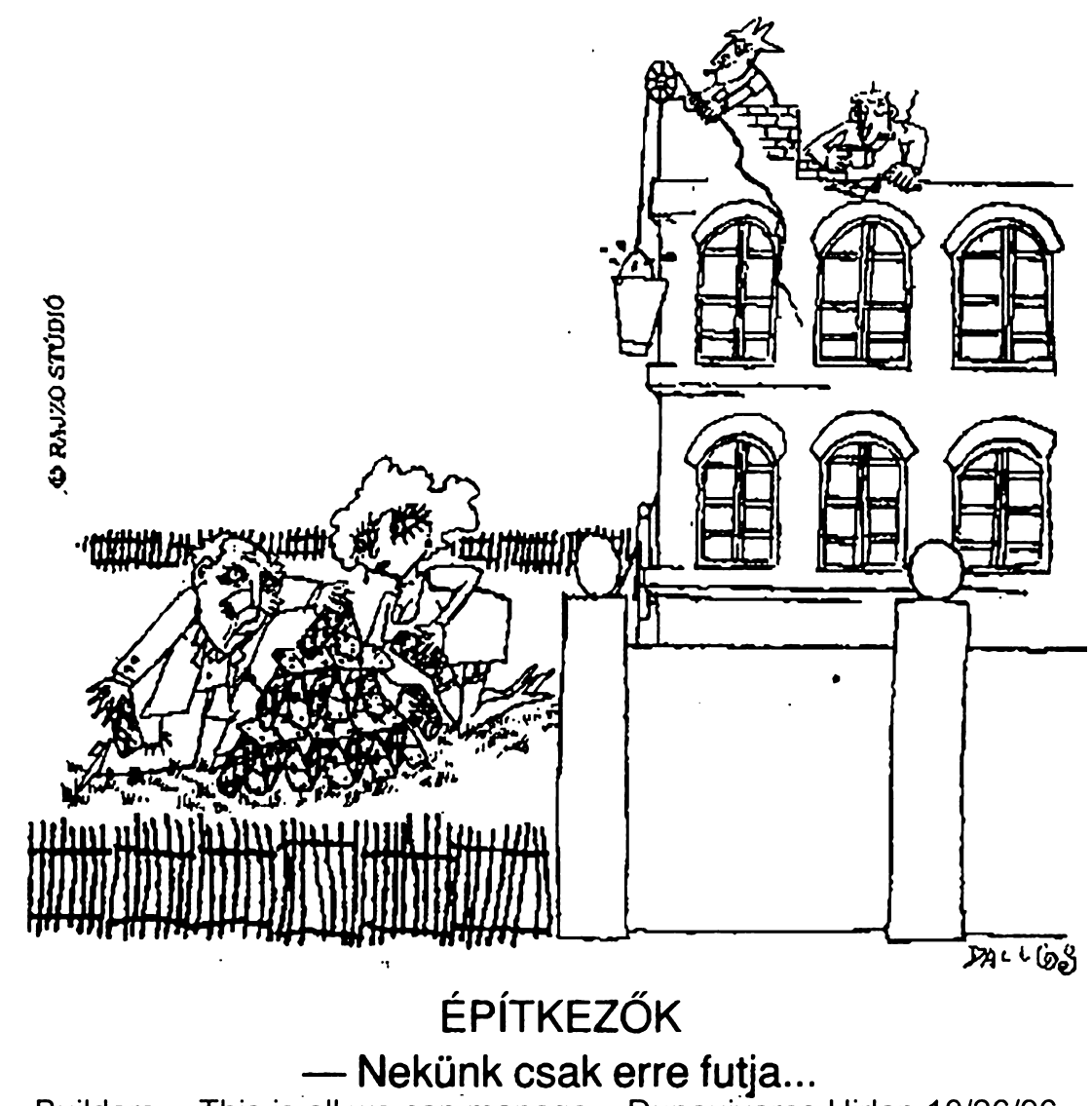

Builders -- This is all we can manage... Dunaujvaros Hirlap 10/26/96

Figure 5. Political cartoons from local and national newspapers highlighted the differences between new house builders in the I990s who used hired, professional labor, and those still attempting to do the building themselves. Reprinted courtesy of the Dunaújvárosi Hírlap. 
modes of production, new building materials, and the new category of House in Hungary person they indexed.

\section{Legitimizing the new family house for Hungary}

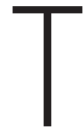

he new house builders of the mid-I99os, like my friend Laura, represented a vanguard with a vision for middle-class life in Hungary. Since such suburban homes had not yet been established, they went out of their way to distinguish themselves from their peasant or working-class neighbors through the material forms of the house and the styles of life they represented. Their cultivated lawns and rock gardens made them anathema to the rural peasantry, for whom the multi-use garage, productive garden or livestock pen indexed a work ethic essential for respectability (Lampland r995:3 I6-323), but also to an older generation of city dwellers with weekend gardens, who were driven to tend, pick, and preserve whatever grew on their plots.

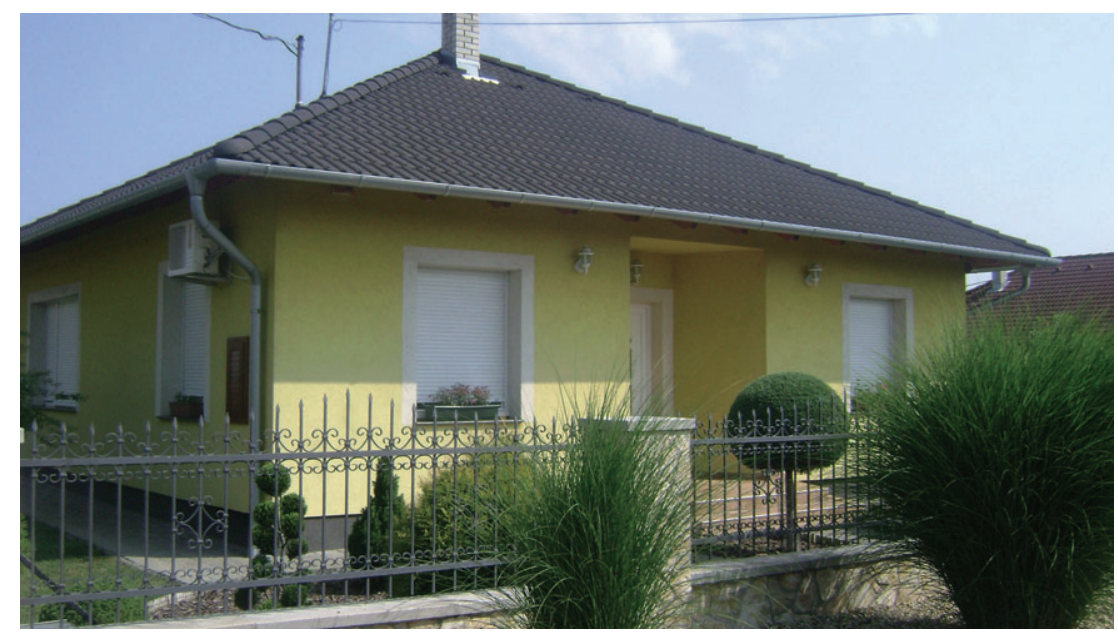

Figure 6. New suburban house in village outside of Dunaújváros, painted lemon yellow. While the simpler house form is more typical of older construction practices, the decorative garden announces its aspirations to new "middle class" belonging. Photo by author, 2008.

At the same time, new family houses were being legitimated by their alignment with a countryside as it was being revalued in opposition to the socialist city; as Raymond Williams has shown, this enduring opposition between country and city is transformed and deployed in times of change (Williams I973). Even though the political economy of building a "family house with garden" had been fundamentally transformed, the new suburban house drew upon continuities with both the weekend cottage and the self-built village house as much as on expectations for middle-class life shaped by the West. With its enclosed garden and gazebos, the new suburban house took on the values once reserved for the cottage, which contrasted the fresh air and the calming effects of being in nature with the pollution and hectic pace of modern city life (Caldwell 20II). In Dunaújváros in particular, with its high rates of childhood asthma attributed to pollution from the steel mill, family houses in the 
country were seen as healthier places to raise children and in general more conducive to a balanced family life. But the new family house ironically was also associated with houses built through kaláka, or selfbuilt. The private sphere of the home, whether of an urban apartment or rural family house, had been idealized as islands of autonomy and privacy from the socialist state. As we have seen, populist writers had looked in particular to provincial peasant entrepreneurs to become the new entrepreneurial classes. These writers lauded the human capacities mobilized by the privately-owned materialities of a family house and its garden. Sándor Kopátsy, for example, an economist and regular contributor to the magazine Family House: The Magazine for Builders, Engineers, Architects, Entrepreneurs and Dreamers, listed the idealized virtues of houses built through kaláka just as it was declining as the primary mode of family house building:

First: Nothing brought together the extended family, the circle of friends, more than mutual building (kaláka). Second: There was no better school for polytechnic capabilities than constructing your own utilities. Many hundreds of thousands learned this way to plaster, to install and repair electricity and plumbing. Third: Nothing brought as much self-confidence as the finished house and its further beautification. A house with a garden promotes the development of everyday feelings of success and happiness. The need to fix something, the first ripe fruit, the most beautiful rose on the block - these make the residents better, more optimistic (Kopátsy I993).

This form of family house, Kopátsy suggested, inculcated a sense of self-sufficiency and pride in the visible fruits of labor on one's own property. In the early I990s, conservative proponents of the family house failed to recognize that the kind of person now building them had no interest in cultivating produce on their property. They were using as little of their own labor as possible in the building process and wanted to avoid the onerous obligations of community-building exchange-though they

divorced, single

mothers and single

men understood

themselves to be

excluded from the

family house, both

as social norm and

as practical

possibility

33 were perfectly willing to exploit their extended family for peripheral labor and financial help.

The very term family house indexed its association with wholesome, heteronormative married life with more than one child. Indeed, divorced, single mothers and single men understood themselves to be excluded from the family house, both as social norm and as practical possibility. The material environment of the family house was supposed to generate tasks inculcating healthy gender subjectivities, particularly for men. For decades, city apartments had been blamed for eliminating the adult male's role and space in the home. Household tasks and childcare remained the responsibility of women, so the man's responsibilities were reduced to drilling holes for hanging pictures and maintaining the family car, if there was one. Masculine identity, it was assumed, would be bolstered by the autonomy of a detached house, building projects and heavier garden work. 
The new family house also provided the space for realizing widespread norms for respectable middle-class life, norms that had been fostered during the state-socialist period but were made untenable by the design and cramped spaces of socialist apartments. These included the expansion of an open plan and individualizing divisions of space. But they also accommodated new desires for spaces associated with modern lifestyles in the West, such as a dedicated master bedroom, bathrooms liberated from drying laundry, and most of all, a large room open to the kitchen for the family to gather. As with the villas of the new economic elite (Czegledy 1998) these houses and their gardens also facilitated business socializing.

Despite the diversity of these new houses, they shared an aesthetic that not only distinguished them from the older housing forms around them, but assisted in their construction as respectable and distinctly Hungarian. The self-built houses of the socialist era were constructed from standardized house designs and had been limited by available technologies, materials and state regulations on size. In contrast, new houses were larger, and displayed clear signs of having been designed by a professional. Their aesthetic did not resemble the commercialized representations of such houses coming from abroad. While most sported the bright-red roofing tiles ubiquitously advertised by multinational firms, the houses themselves were rarely white and rectilinear. Instead, they developed for the exterior an aesthetic that had emerged for interiors during the I970s, one that transformed and appropriated a state-socialist version of modernism with organicist forms and materials. Unlike postmodern forms in the West that featured fragmentation and renewed attention to façade, these housing forms reflected the particular disenchantment with the alternative modernity being produced by the socialist state and its politicization. In a condemnation of the straight-line, the rectilinear form and the standardization dictated by principles of effciency, this aesthetic featured asymmetric and rounded motifs, including undulating roofs, round columns and arched windows. In opposition to the artificial, mass-produced materials favored by the socialist state, these houses made prominent use of "natural" materials, such as wood, stone, and even reed thatch. ${ }^{14}$ And in a rejection of the moralizing aestheticism of socialist modernism, this aesthetic promoted color, play and fantasy. As we will see in the examples below, house builders carefully choose among the variety of design elements available to them, attempting to position themselves as part of this more exclusive middle class, and yet marking their respectability through material signs of modesty and virtue.

Despite widespread mourning for the lost security offered by state socialism, discourses on new family houses and renovated interiors aligned with this critique of the socialist modern project, not only its attempt to dominate the natural world, but its profound misunderstanding of the malleability of human nature. In this way, the material aesthetics of family houses reinforced acceptance of neoliberal ideologies even they clashed with lived experience of austerity measures, unem- 
ployment, radical income inequalities, and failing medical, educational and transportation systems. The values materialized in an anti-socialist aesthetics legitimated these new suburban house forms along with the diverging fortunes they represented.

\section{Appropriating the new family house}

B y the mid-I990s, anyone aspiring to new middle class status had to face the often contentious question of whether or not to build a family house, and if so, what form the house would take. Here I give two examples. Csilla, about 35 at the time, was a director in the steel mill whose parents had been unskilled factory workers. While on some occasions she was very happy with her urban apartment, she increasingly echoed widespread discourses in voicing her longings to move to the "peace and quiet" of the countryside, to "escape the panel masses" which she found so claustrophobic. Her husband János was against the idea. His extended family had all lived in villages, and he wanted nothing to do with the labor, the flies and the smells he associated with rural living. As a factory driver and hand-ball coach, he also assumed a new family house was for the wealthy directors, and simply inaccessible to someone of even Csilla's rank.

In another family, Margit, a lawyer in her late 40s, resisted her husband Géza's emerging desires for a house. For a time, both had been disdainful of the trend. They discounted conservative rhetoric which framed such houses as regenerating the extended family and presocialist values and instead regarded them as symbols of the nouveau riches. Nonetheless, Géza's dissatisfaction with the panel construction apartment grew, fueled by that of their I8-year-old son. Margit continued in her opposition, well understanding the burdens of a house in the village-its isolation and spotty public transportation-to fall on the woman's shoulders. More importantly, she could not assimilate the family house into her identity as a member of an urban, polgár intelligentsia.

By the end of the decade, however, both families had moved to such houses. In Csilla's case, János had been unwilling to help with the contracting necessary to build a new house, so, she found an existing one for sale in a nearby village. It was built in the late I980s in a neighborhood of similar houses, with several peasant houses nearby, but not far from a developing suburban neighborhood. They refurbished the interior, painted the exterior a moss green, and installed a Finnish sauna. Though it was not what Csilla had hoped for, it was near the field where she had developed a passion for horseback-riding. She made sure they got several dogs and a cat to provide their ro-year-old son-otherwise glued to the computer screen-with a "healthy" country experience. János began to spend far more time at home. For both, the form of their house provoked few anxieties about their class status. In fact, evidence of Csilla's ample salary spilled over into the driveway where they parked their new Volvo.

With Margit's eventual blessing, Géza, who was an engineer at a division of the privatizing steel factory, had his dream house designed and 

professional women's handball team, a former Party secretary, and a truck driver. The house was equipped with the latest technologies, was painted a dark watermelon pink, and the roof overhang was inlaid with wood. The interior was spacious and well-appointed, but it made symbolic concessions to Margit's requirements for modesty and practicality. For example, it had no fireplace. "Who would clean it?" she asked. The large, luxurious bathroom-modeled on one Margit had seen a London hotel room-had a walk-in shower but no tub: "In this busy world, who has time to take baths?" When I visited them in 2000, Margit commented that this neighborhood was where Dunaújváros's middle class was moving, using the term middle class (középosztály) rather than polgár. When I objected that this area was hardly for the average Hungarian, she conceded: "Yes, unfortunately in Hungary the middle class is very small." As for her neighbors, she was only dissatisfied with two, both based on the form of their houses rather than their professions. One had an oval-shaped roof that had apparently collapsed several times, a sign of the builder's irresponsibility and desire for extravagance beyond his abilities. The other had small statues of cherubs and fountains in the bricked in front yard - a sure sign for her that the family was Roma.

\section{Conclusion}

\rceil he material requirements for the imagined standards of living of "first world" middle class citizens have come to shape the emergence of middle class culture in Hungary, particularly in the emergence of a housing form unique in its materialization of contemporary ideals. While the imagined benefits of such materialities are immense, falling out of the middle class is no longer experienced solely in local terms. It is conceptualized as failing to claim membership in a first world translocal social order, and thus risking the invisibility of $3^{\text {rd }}$ world status (Foster 2002:I33-35, Liechty 2003:I38-I4I; O'Dougherty 2002; Patico 2008). However, as we have seen through the new, suburban family house, the incorporation of such standards is neither immediate nor unchallenged.

The family house form in Hungary has not been one of enduring cultural value, but has acquired newly invigorated value by virtue of its opposition to the ideology claimed for state socialist architecture (Miller I984; May I988). The family house, symbolically-opposed to the socialist modern apartment blocks which came to stand for the collective, artificial uniformity and forced egalitarianism of state-socialism and the working classes, now appears as the embodiment of the "natural" values of capitalism. Even though urban apartment blocks continue to house a diverse spectrum of Hungarian society, including many who claim middle-class status, the new suburban house has successfully been aligned through discourse and material forms with the weekend cottage, contrasting the calming effects of nature with the invigorating (or nervewracking) effects of modern city life, but also with the self-built family 
The materiality of house of the rural-entrepreneur. It thus appears both continuous and inevitable, coalescing into one form two values forged in opposition to

the new family state socialism: the romanticization of nature and the idealization of the house has not only private sphere (cf. Frykman and Löfgren 1987). The gradual triumph of this form transformed local systems of value just as the form itself develredefined the oped according to the aesthetic specificities of the Hungarian context. In the process, the materiality of the new family house has not only redeconditions for fined the conditions for belonging to the ranks of respectable society, but belonging to the has been instrumental in constituting and legitimating this emerging class.

ranks of

respectable society,

but has been

instrumental in

constituting and

legitimating this

emerging class
Acknowledgments. This article is a synthesis of papers presented at several conferences and commented upon by many generous colleagues and friends. I would like to thank in particular participants at the NSF /University of Michigan Workshop on the Cultural Politics of Globalization and Community in East Central Europe and at the SAR conference on the Global Middle Classes, as well as writing group fellows Miranda Johnson, Lara Kusnetzky, Eric Karchmer, Jennie Burnett and Laura Ring. I also very much appreciated the insightful comments of the two anonymous reviewers for City and Society. As always, my thanks go to Matthew Hull and Deborah Cornelius for their support and inspiration, and to all the people in Dunaújváros who graciously welcomed me into their homes.

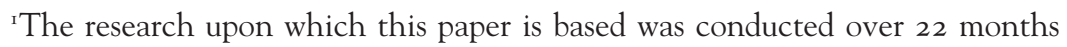
in Budapest and Dunaújváros in 1996-1997, and during shorter trips in 1994, $2000,2004,2008$. I lived in several areas of the town and also in one of the suburbanizing villages, conducting formal and informal interviews with building, design and real estate professionals, civil servants, entrepreneurs and a wide range of people who understood themselves to be deserving of a middle class status. I also conducted archival research at the city land registry office, the steel mill museum, the town library and the city museum Intercisa. In 1997 I participated in a sociological survey interviewing families about their experience of the city in more than 25 apartments and houses in four different city districts. All in all, I visited over 80 apartments, houses and weekend cottages. Funding for fieldwork was provided by the Fulbright Commission (IIE) and the Social Science Research Council (IREX).

${ }^{2}$ As writer Sándor Kopátsy opined in I993, "We will not be truly European when we are accepted into the European Union, but only when most families can say, 'My house is my castle' " (Családi Ház I993:52).

${ }^{3}$ This kind of "suburbanization" did not begin until the late I980s, even in the metropolitan capital city of Budapest, where it took off in the r 990 (see Valuch 2004:550). Precedents included the remnants of a turn-of-the-century bourgeois villa culture in larger cities, but also a middle class "family house with garden" form built in the interwar period primarily in Budapest and its surrounding fringesthough some versions of it could also be found in provincial towns, built predominantly for "a lower middle class of office workers, artisans and skilled workers" (Kósa 2000:1 87).

${ }^{4}$ Caroline Humphrey (2002), in contrast, shows how the large, red brick houses of New Russians in the former Soviet Union appeared to be luxurious residences, but in fact, were often rendered uninhabitable by their disconnect from the local infrastructure and society. 
${ }^{5}$ Even in Budapest, private self-built residential units made up the majority of new construction in the I990s. In 2000, the state began to subsidize interest rates, and in 2004, introduced new regulations allowing commercial banks to offer much cheaper mortgages to home buyers in foreign currency (Bodnár and Molnár 20I0:797). Many Hungarians took advantage of these mortgages to invest in real estate, but the economic crisis of 2008 left them holding foreign currency debts that had mushroomed with the fall of the Hungarian currency.

${ }^{6}$ The appellation "middle stratum" was in a sense justified, given that the means of production were largely controlled by the state, no segment of the population owned much capital, and the population enjoying this modern lifestyle included as much of the skilled working class (predicted to become the universal class) as it did white-collar professionals and Party elites.

'Fidesz: Magyar Polgári Szovetség in power from I998-2002, and 2010 to present.

${ }^{8}$ Bodnár (2007:142) writes that in Hungary “ 'bourgeois' (polgári) as an adjective in everyday parlance has little to do with the propertied bourgeoisie; rather, it is used as the incarnation of objects, lifestyles, manners, and arrangements that have been proven solid, efficient, and good."

${ }^{9} 13^{\text {th }}$ Congress of the Hungarian Socialist Workers Party, as reported by the $\mathrm{BBC}$, broadcast $4 / 8 / 85$.

${ }^{10}$ Daniel Miller (1984) describes a similar process in England, although there Modernist architecture has been used primarily for large corporate structures or for public housing for the poor. The family house form, he argues, is not of enduring cultural value, but acquires new value by virtue of its opposition to the progressive ideology claimed for modernist architecture.

${ }^{11}$ The I 5 -year housing plan of I 960 was a lightning rod for contentious debates over the appropriate housing form for the development of socialism (Major and Osskó i98I; Molnár 20ıо).

${ }^{12}$ This form of building is remarkably similar to that described by James Holston for urban peripheries in Brazil, where poor working class families spend to to 20 years transforming squatter shacks into masonry houses on seized land in order to establish themselves as propertied citizens, and are transformed by the process (I99I:45I).

${ }^{13}$ The only financial incentive for building a house at this time was the price of land. Newly formed local governments, the result of radical decentralization, had few resources to apply to development. They tried to attract house builders by offering plots of land at discount rates, running a rough road through these plots, and promising (eventually) to provide running water and electricity.

${ }^{14}$ From the late i960s, a group of dissident architects founded an Organicist school aligned with previous architectural styles in Hungarian history (particularly Art Nouveau or Szecesszió); their designs were in direct opposition to what they saw as the abstract and dehumanizing effect of socialist modern architecture. While their designs had some influence over vernacular taste, they were not widely known until the ig8os.

\section{References cited}

Bánk, András

I967 A gyerek helye. (The child's place). Lakáskúltura, 3-7.

Berdahl, Daphne

I999 Where the World Ended: Re-Unification and Identity in the German Borderland. Los Angeles: University of California Press.

Bodnár, Judit

2007 Becoming Bourgeois: (Postsocialist) Utopias of Isolation and Civilization. In Evil Paradises: Dreamworlds of Neoliberalism. Mike Davis and Daniel Bertrand Monk, eds. Pp. i40-I6r. New York: The New Press. 
Bodnár, Judit, and Virág Molnár

2010 Reconfiguring Private and Public: State, Capital and New Housing Developments in Berlin and Budapest. Urban Studies 47(4):789-8 I 2.

Buchowski, Michal

2008 The Enigma of the Middle Class: A Case Study of Entrepreneurs in Poland.

In Changing Economies and Changing Identities in Postsocialist Eastern

Europe. Ingo W. Schroder and Asta Vonderau, eds. Pp.47-74. Berlin: LIT Verlag.

Caldwell, Melissa

20 I I Dacha Idylls: Living Organically in Russia's Countryside. Berkeley: University of California Press.

Czegledy, André P.

I998 Villas of Wealth: A Historical Perspective on New Residences in PostSocialist Hungary. City and Society Io(I):245-268.

Dunaújvárosi Hírlap, 8/ı996: I.

Fehérváry, Krisztina

2002 American Kitchens, Luxury Bathrooms and the Search for a "Normal" Life in Post-Socialist Hungary. Ethnos 67(3):369-400.

Ferge, Zsuzsa

I 997 Polgárosodó Magyarország: Lefokozott szocialpolitika.(Hungarian Embourgeoisement: Dwindling Welfare Politics) i68 Ora, Pp.ı8-ı9.

Foster, Robert J

2002 Materializing the Nation: Commodities, Consumption and Media in Papua

New Guinea. Bloomington: Indiana University Press.

Freeman, Carla

2007 The Reputation of Neoliberalism. American Ethnologist 34(2):252267.

Frykman, Jonas, and Orvar Löfgren, eds.

I987 Clean and Proper: Body and Soul through Peasant and Bourgeois Eyes. New Brunswick: Rutgers University Press.

Habermas, Jürgen

I971 [1962]. A társadalmi nyilvánosság szerkezetváltozása (The Structural Transformation of the Public Sphere: An Inquiry into a Category of Bourgeois Society) Zoltán Endreffy, translator. Budapest: Gondolat Könyvkiadó.

Hegedüs, József

1992 Self-Help Housing in Hungary: The Changing Role of Private Housing Provision in Eastern Europe. In Beyond Self-Help Housing. Kosta Mathéy, ed. Pp.2 I 7-23r. Munich: Profil Verlag.

Holston, James

I99I Autoconstruction in Working-Class Brazil. Cultural Anthropology $6(4): 447-465$.

Humphrey, Caroline

I 997 The Villas of the 'New Russians': A Sketch of Consumption and Cultural Identity in Post-Soviet Landscapes. Focaal 30/31:85-106.

Jackson, Kenneth

I 987 Crabgrass Frontier: The Suburbanization of the United States. New York:

Oxford University Press.

Keane, Webb

2003 Semiotics and the Social Analysis of Material Things. Language and Communication 23:409-25.

2006 Subjects and Objects. In Handbook of Material Culture. Christopher Tilley et al., eds. Pp.r97-202. London and Thousand Oaks, California: Sage Publications. 
Kenedi, János

I98 I Do it Yourself: Hungary's Hidden Economy. London: Pluto Press.

Konrád, György (George)

I984 Antipolitics. [Transl. Richard E. Allen] San Diego: Harcourt Brace Jovanovich.

Kopátsy, Sándor

I 993 Nemcsak Ház a Családi Ház (The Family House is Not Just a House). Családi Ház: Építkezôk, építtetôk, építészek, vállalkozók és reménykedôk lapja. (Family House: The Magazine for Builders, Engineers, Architects, Entrepreneurs and Dreamers.) V(I):52.

Kósa, László

2000. The Age of Bourgeois Society, I920-I948. Everyday Culture. In A Cultural History of Hungary In the Nineteenth and Twentieth Centuries. László Kósa, ed. Pp. I 77-2 Io. Budapest: Corvina/Osiris.

Lampland, Martha

I 995 The Object of Labor: Commodification in Socialist Hungary. Chicago: University of Chicago Press.

Latour, Bruno

2005 Reassembling the Social: An Introduction to Actor-Network-theory. Oxford: Oxford University Press.

Liechty, Mark

2003 Suitably Modern: Making Middle-Class Culture in a New Consumer Society. Princeton: Princeton University Press.

Magyar Nemzet.

1996. Erejük felett építkeznek a családok: kalákában egy négyzetméter negyvenegyezer forint. (Families building above their powers: in self-build one meter squared is 40,000 forints). Magyar Nemzet, 15 October.

Major Maté and Judit Osskó

I98 I Új építészet, új társadalom I945-I978: Válogatás az elmúlt évtizedek építészeti vitáiból, dokumentumaiból. (New Architecture, New Society) Budapest: Corvina Kiadó.

May, Elaine Tyler

I988 Homeward Bound: American Families in the Cold War Era. New York: Basic Books.

Miller, Daniel

I984 Modernism and Suburbia as Material Ideology. In Ideology, Power and Prehistory. Daniel Miller and Christopher Tilley, eds. Pp.37-49. Cambridge: Cambridge University Press.

I987 Material Culture and Mass Consumption. Oxford: Basil Blackwell.

2005 Introduction. In Materiality. Daniel Miller, ed. Pp.I-50. Durham: Duke University Press.

Miskolczi, Miklós

I980 Város lesz, csakazértis. . (There will be a city, despite it all. . .) Budapest: Szépirodalmi Konyvkiadó.

Molnár, Virág.

20Io. In Search of the Ideal Socialist Home in Post-Stalinist Hungary: Prefabricated Mass Housing or Do-It-Yourself Family Home? Journal of Design History $23(\mathrm{I}): 6 \mathrm{I}-8 \mathrm{I}$.

Munn, Nancy

I986 The Fame of Gawa. A Symbolic Study of Value Transformation in a Massim (Papua New Guinea) Society. Durham: Duke University Press.

O'Dougherty, Maureen

2002 Consumption Intensified: The Politics of Middle-Class Daily Life in Brazil.

Durham: Duke University Press. 
Patico, Jennifer

2008 Consumption and Social Change in a Post-Soviet Middle Class. Washington: Woodrow Wilson Press; Stanford: Stanford University Press.

Pittaway, Mark

2000 Stalinism, Working-Class Housing and Individual Autonomy: The Encouragement of Private House Building in Hungary's Mining Areas, I950-54. In Style and Socialism: Modernity and Material Culture in Post-War Eastern Europe. Susan Reid and David Crowley, eds. Pp. 49-64. Oxford: Berg.

Rausing, Sigrid

I 998 Signs of the New Nation: gift exchange, consumption and aid on a former collective farm in north-west Estonia. In Material Cultures: Why Some Things Matter. Daniel Miller, ed. Pp. I89-213. Chicago: University of Chicago Press.

Róna-Tas, Ákos

I 997 The Great Surprise of the Small Transformation: The Demise of Communism and the Rise of the Private Sector in Hungary. Ann Arbor: University of Michigan Press.

Ruble, Blair

I 995 Money Sings: The Changing Politics of Urban Space in Post-Soviet Yaroslavl. Cambridge: Woodrow Wilson Center and Cambridge University Press.

S. Nagy, Katalin

I987 Lakberendezési Szokások. (Home Furnishing Customs) Budapest: Magvetö Kiadó.

Shyer, Charles

I99I Father of the Bride. Sandollar Productions.

Sik, Endre

I 988 Reciprocal Exchange of Labour in Hungary. In On Work. Historical, Comparative and Theoretical Approaches. Ray E. Pahl, ed. Pp.527-547. Oxford: Blackwell.

Szelényi, Ivan

I988 Socialist Entrepreneurs: Embourgeoisment in Rural Hungary. With Robert Mancin, Pál Juhász, Bálint Magyar, and Bill Martin. Madison: University of Wisconsin Press.

Tilley, Christopher 2007 Materiality in Materials. Archaeological Dialogues I4(I): I6-20.

Valuch, Tibor.

2004 Changes in the Structure and Lifestyle of the Hungarian Society in the Second Half of the XXth Century. In Social History of Hungary from the Reform Era to the End of the Twentieth Century. G. Gyányi, G. Kövér and T. Valuch, eds. Pp. 5I I-672. Highland Lakes: Atlantic Research and Publications, Inc.

Verdery, Katherine.

2003 The Vanishing Hectare: Property and Value in Postsocialist Transylvania. Ithaca: Cornell University Press.

Williams, Raymond

I973 The Country and the City. New York: Oxford University Press.

Zhang, Li

2008 Private Homes, Distinct Lifestyles: Performing a New Middle Class. In Privatizing China: Socialism From Afar. Li Zhang and Aihwa Ong, eds. Pp. Ithaca: Cornell University Press. 